\title{
Tissue engineering of vascular/valvular equivalents on the base of the xenogeneic decellularized matrix
}

\author{
M. V. Savchuk \\ State Instituton «Institute of urgent and recovery surgery named after V. K. Gusak National Academy of Medical Science of Ukraine» \\ 47, Leninskyi Ave., Donetsk, Ukraine, 83045 \\ pmv-07@yandex.ru
}

\begin{abstract}
According to the WHO, in 2008 cardiovascular diseases claimed the lives of 17.5 million people (30\% of all diseases). Often the only option to save a patient's life is a replacing the injured part of an organ by the prosthesis. Aim. This research was aimed to produce biomodificated cardiovascular graft by decellularisation of porcine heart valve. Methods. Our method of decellularization permits to make morphologically and physically non-modified decellularised extracellular matrix. Results. The analysis of matrix shows a decrease of the total number of cells, preservation of the collagen and elastin fibers structure, and safety of physiological adhesion. Conclusions. The matrix can be used as a framework for the vessel-valvular tissue-engineering prosthesis after its recellularization by the recipient's autologous cells.
\end{abstract}

Keywords: tissue engineering, extracellular matrix, decellularization.

Introduction. Each year, cardiovascular diseases claim the lives of millions of people, and are the prevailing cause of death for last two decades. Often the only option to save a patient's life is a replacing the injured part of an organ by the prosthesis. Annually in the world about 275,000 of such surgeries have been performed. Surgical replacement by either mechanical or bioprosthetic heart valves is the most common treatment for the end-stage valvular diseases $[1,2]$.

Mechanical valves display good structural durability but are associated with some problems for recipients. The mechanical prostheses are unable to provide full adaptation to physiological environment such as the pressure change and strength characteristics, since the non-living materials are used for their production [3]. For the same reason, they are not capable of growth and development in the body, which makes them unsuitable in pediatric cardiac surgery. Furthermore, the use of mechanical prostheses can cause the thromboembolic disease which needs lifelong anticoagulant therapy [4-6].

Bioprosthetic heart valve replacements are either of animal origin (xenografts), such as porcine aortic val-

(c) Institute of Molecular Biology and Genetics, NAS of Ukraine, 2014 ves and bovine pericardial valves, or taken from human donors (homografts). Usage of xenografts makes it possible to have the valves of different sizes stored and available off-the-shelf. Moreover they enable to avoid anticoagulative therapy and have a potential of remodeling in recipient's organism [7]. Several attempts have been made to create functional heart valve replacements able to grow as a patient grows older, to be repaired and remodeled. With the approach of tissue engineering, the patient's own cells are isolated, e. g. from a bone marrow, and seeded onto prepared matrices, in the three-dimensional structure (for example, extracellular matrix (ECM) of xenografts previously decellularized) [4].

All tissues and organs are made up of cells and an associated extracellular matrix - a secreted product of the resident cells consisting of a unique, tissue-specific three-dimensional environment of structural and functional molecules. They are usually regarded as cells with a supporting stroma.

So, the success in creating viable autologous cardiovascular graft depends on three main elements: autologous cells suitable phenotypically and functionally; a matrix as a temporary scaffold that gives the tissue strength as long as the new extracellular matrix with 
autologous cells is being synthesized; the tissue formation and development under the in vitro conditions close to the physiological ones [3].

The extracellular matrix is viewed in terms of its role in structural maintenance and three-dimensional shape of the respective tissue or organ. However, the extracellular matrix is the microenvironmental niche, and it is in the dynamic reciprocity with the resident cell population. That is why the phenotype of the resident cells, including their active genetic profile, proteome, and functionality, is influenced by the conditions of their microenvironmental niche. Thus, the native extracellular matrix is a logical and ideal scaffold for the organ and tissue reconstruction.

Moreover, structural and functional molecules in the extracellular matrix (glycosaminoglycans, collagen, elastin, fibronectin, laminin, and vitronectin) are highly conserved proteins in eukaryotic organisms, which largely explains the absence of an adverse immune response after xenotransplantation [8].

There are evidences that grafts failure, at least in part, is a result of immunological reactions, caused by cellular elements remaining in the homograft's matrix, that trigger the immune reaction by the receiver. The endothelial cells and fibroblasts are able to express Class I and II histocompatibility complex that are recognized by the receiver's immune system and can be a cause of tissue degeneration and graft failure [9].

The decellularization of xenogeneic matrices is a possibility to prevent the graft failure induced by the immune response. Moreover, it is a chance to create a patient specific viable heart valve with tissue engineering (TE) techniques. There are the studies suggesting that decellularized heterografts lead to a reduced inflammatory response of the receiver and are able to be progressively repopulated by the autologous cells [9].

The main purpose of decellularization is to remove all cellular components, by maintaining intact the structural elements of the extracellular matrix. Of today, several methods of the pre-transplant treatment of transplants have been developed. They provide a donor cell death without using crosslinking agents, and a subsequent colonization of the recipient cells prior to implantation [10].

Of now, a variety of tissue decellularization methods have been developed in the world. All of them can be assembled into two main groups: methods, suggesting the use of substances that cause necrosis; and methods allowing decellularization by inducing apoptotic cell death. Both groups have their pros and cons [10-15].

The method of decellularization with the calciumfree solution of ethylenediaminetetraacetic acid (EDTA) belongs to the apoptosis-inducing methods. EDTA is a chelate, which is able to bind calcium ions, so that the interaction between cadherins becomes broken, which results in cells dissociation. At the same time, according to the published data, it is possible that EDTA in high concentration initiates the apoptosis processes $[12,15]$.

However, it should be noted that the method of decellularization with the EDTA does not allow achieving a complete removal of dead cells from the depth of the matrix. Perhaps, this is due to the fact that cells can migrate from the surface of the tissue to its depth because of the negative chemotaxis. On the other hand, it is common knowledge that apoptosis can be realized till the end in vivo with macrophages [15].

The aim of research is to assess the effective conditions of apoptosis-inducing decellularization of xenogeneic valves, and to evaluate the integrity and physiological intactness of the obtained extracellular matrix during decellularization of heart valves.

Materials and methods. The research was performed with cardiac valves of 6-month-old pigs $(n=7)$. Heart sampling was carried out in the operating room conditions in accordance with the requirements of $\mathrm{Eu}$ ropean Convention for the Protection of Vertebrate Animals Used for Experimental and Other Scientific Purposes (Strasbourg, 1986) and the statements of the $1^{\text {st }}$ National Congress on Bioethics (Kyiv, 2001). The valves were derived under sterile conditions on the average four hours after heart sampling. The obtained samples were exposed in apoptosis-inducing solution of 10 mM EDTA («Sigma», USA) for two days. After exposure the samples were carefully washed in the medium with salts of concentration close to physiological one.

Such kind of decellularization by inducing apoptosis was firstly proposed by Akatov and his colleagues Russian scientists of Bakoulev Scientific Center for Cardiovascular Surgery [16]. In spite of advantages of the apoptosis-inducing method of decellularisation, there are some complexities in it. Therefore, the authors offered to use DMEM as a solvent for EDTA. 
We supposed that the medium Eagle MEM without $\mathrm{Ca}^{2+}$ is a better solvent for EDTA as a chelate of calcium ions. Due to the usage of this modification of medium we could reduce the washing time after decellularisation solution to two days. Moreover, we permanently mixed up the medium with the decellularised graft by roller, which helps us to increase the efficiency of decellularisation. Our modification of the Akatov's decellularisation method, is protected by the Ukrainian patent N 85240.

To examine the efficiency of apoptosis initiation, the tissue integrity and cell removing samples were analyzed histologically. Slices of each conduit were embedded in paraffin. For general morphology, three sections (5 $\mu \mathrm{m})$ of each slice were stained with hematoxylin and eosin [17]; underwent special staining (Apoptag ${ }^{\circledR}$ Peroxidase ISOL Kit, «Chemicon», USA) [www. millipore. $\mathrm{com} /$ catalogue/item/s7200] to allow the identification of breaks in DNA at initial stages of apoptosis [18]; and stained according to Verhoeff to evaluate the state of elastic and collagen fibers for assessment of safety of extracellular matrix strength and flexibility [17].

To assess adhesive properties of matrix the decellularized grafts were incubated with human fetal fibroblasts derived and cultured according to the standard method [19]. Before incubation the culture of fibroblasts was stained with vital fluorescent dye PKH 67 Green («Sigma») and resuspended in cultural medium. The adhesion rate of decellularized tissue of cardiac valves was estimated by the fifth day of incubation using fluorescent microscopy.

Results and discussion. Specimens of decellularized porcine matrix were not cell-free in the leaflets and the conduit wall. Histological analysis revealed just a decrease in the total number of cells, appearance of pronounced changes in nuclei morphology in most of them (karyopyknosis, karyorhexis) testifying to the successful initiation of apoptosis (Fig. 1, $A$ ). The cells of control (intact) samples on the contrary had normal morphological characteristic for fibroblasts: extended spindleshaped cells with oval shaped nucleus (Fig. 1,B) [20,21].

Specific staining with Apoptag ${ }^{\circledR}$ peroxidase showed different content of cells at the apoptosis state in various structures of valve (Fig. 2). The highest number of the apoptotic cells was found in the leaflet. This may be associated with its relative thinness if compared with the vessel wall or the annulus fibrosis region that could simplify the penetration of treating solution deep into the structure and following apoptosis induction. Additionally, a larger number of viable cells in tissue depth, if compared with superficial zones in regions with complicated structure, is also associated with the cell migration due to the negative chemotaxis $[21,22]$.

Histological analysis of the sections after specific staining for extracellular matrix showed good preservation of the matrix architecture [23,24], the structure and orientation of collagen and elastin fibers after decellularization are safe. The staining of extracellular matrix fibers according Verhoeff was successful in both aorta wall area (maroon color) and valve leaflet area (crimson color) (Fig. 3).

A fluorescent analysis of supposed transplants revealed the bright fluorescencing cells adhered to connective tissue matrix under violet blue excitation, which shows the preservation of adhesive properties of the extracellular matrix and its availability for further colonization with tissue-forming autologous cells of the recipient.

The present study provides evidence of a successful in vitro producing of tissue engineered grafts, fits for the reconstruction of heart valve. The described method of tissue engineering is based on decellularization of porcine heart valves by inducing apoptotic cell death with the calcium-free solution with EDTA. According to the obtained data we may suggest that EDTA solution of 10 $\mathrm{mM}$ as well as the proposed scheme of grafts treatment are effective in terms of decellularization. As we expected this type of tissue treatment induces apoptotic cell death in the donor grafts, total number of cells decreases, the changes in nuclei morphology (karyopyknosis, karyorhexis) in most part of remaining cells appear, but the total decellularization of tissue is not reached in vitro. The initiation of apoptosis in valve leaflet as well as on the surface of the valve vascular region was efficient. The initiation of apoptosis was not uniform in different structures of xenograft.

Conclusions. Positive specific staining of extracellular matrix and results of its fluorescent analysis allowed a suggestion that the matrix saves its physiological integrity after decellularization. After treatment with decellularizing solution, the connective tissue matrix of grafts preserved its morphofunctional and adhesive properties. Therefore it would be suitable for further colo- 

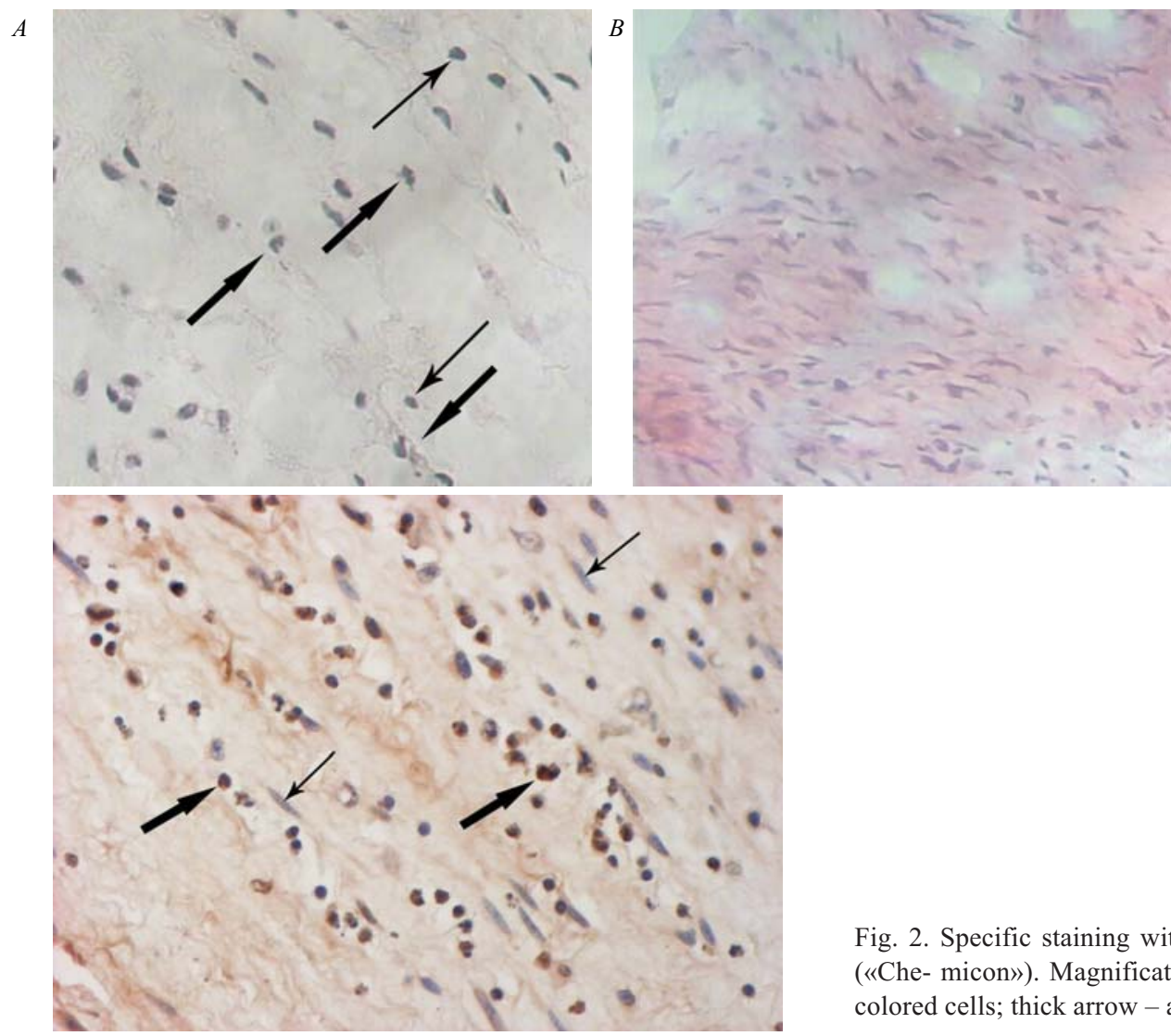

$A$

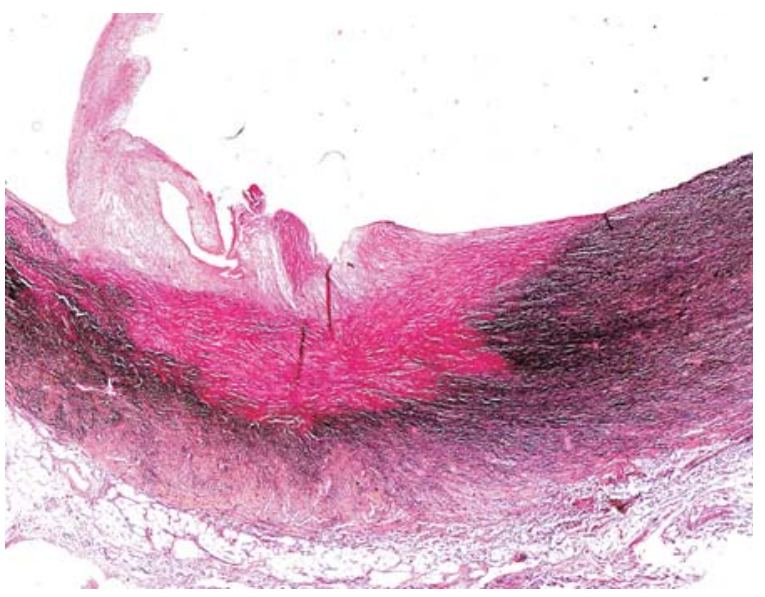

C

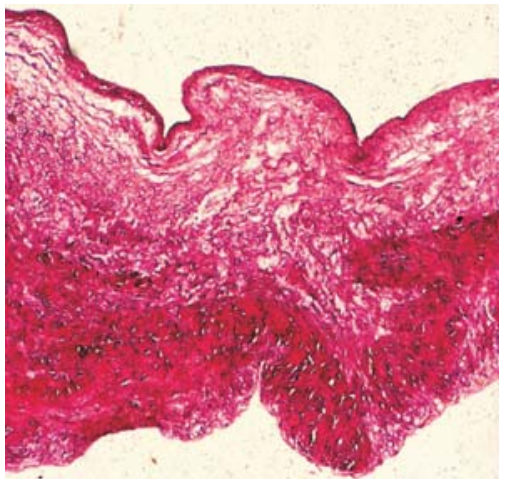

$B$ leaflet
Fig. 1. Results of hematoxylin and eosin staining (light microscope, magnification $\times 400)$ : $A$ - specimens after decellularization (thin arrow - karyopyknosis; thick arrow - karyorhexis); $B$ - control (intact) samples

Fig. 2. Specific staining with Apoptag ${ }^{\circledR}$ Peroxidase ISOL Kit $(«$ Che- micon»). Magnification $\times 225$. Thin arrow - alive blue colored cells; thick arrow - apoptotic brown colored cells

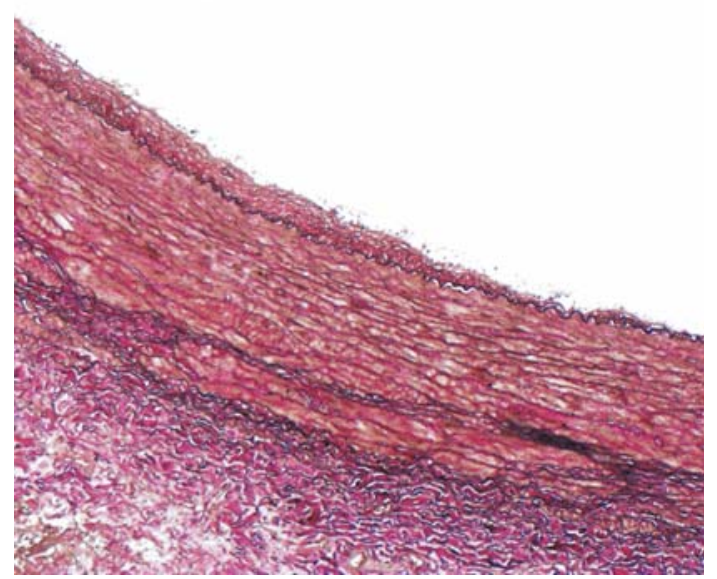

Fig. 3. Result of extracellular matrix staining according to Verhoeff; light microscope, magnification $\times 30: A$ - specimens after decellularization; $B$-normal aorta wall; $C$-normal valve 
nization by autologous recipient cells (to realize the revitalization) and use as a tissue-engineered cardiovascular prosthesis.

Тканинно-інженерний судинно-клапанний еквівалент на основі ксеногенного децелюльованого матриксу

\section{М. В. Савчук}

\section{Резюме}

Згідно з даними ВООЗ, у 2008 рочі в світі від сериево-судинних захворювань померло 17,5 млн людей (30\% усіх захворювань). Часто єдино можливим варіантом спасіння життя пацієнта є заміна пошкодженої ділянки органа протезом. Мета. Отримання біомодифікованого сердиево-судинного графта за рахунок децелюляризачії сериевого клапана свині. Методи. Технологія одержання морфологічно і фізично не зміненого децелюляризований екстраиелюлярного матриксу. Результати. Аналіз матриксу демонструє зниження загальної кількості клітин, збереже- ність структури колагенових та еластинових волокон, а також фізіологічної адгезивності матриксу. Висновки. Матрикс після деиелюляризачії є придатним для використання як каркаса для судинно-клапанного тканинно-інженерного протезу після його рецелюляризації аутологічними клітинами реципієнта.

Ключові слова: тканинна інженерія, екстрачелюлярний матрикс, децелюляризачія.

Тканеинженерный сосудисто-клапанный эквивалент на основе ксеногенного децеллюлированного матрикса

М. В. Савчук

Резюме

Согласно данным ВОЗ, в 2008 году в мире от сердечно-сосудистых заболеваний умерли 17,5 млн человек (30\% всех заболеваний). Часто единственно возможным вариантом спасения жизни паичента является замена поврежденного участка органа протезом. Цель. Получение биомодифииированного сердечно-сосудистого графта вследствие децеллюлирования свиного сердечного клапана. Методы. Наша технология позволяет получить морфологически и физически не измененный децеллюлированный экстраиеллюлярный матрикс. Результаты. Анализ матрикса демонстрирует снижение общего количества клеток, сохранность структуры коллагеновых и эластиновых волокон, а также физиологической адгезивности матрикса. Выводы. Таким образом, матрикс является пригодным для использования его в качестве каркаса сосудисто-клапанного ткане-инженерного протеза после рецеллюляризации аутологичными клетками рециииента.

Ключевые слова: тканевая инженерия, экстрачеллюлярный матрикс, децеллюляризация.

\section{REFERENCES}

1. Hoerstrup SP, Sodian R, Daebritz S, Wang J, Bacha EA, Martin $D P$, Moran AM, Guleserian KJ, Sperling JS, Kaushal S, Vacant $J P$, Schoen FJ, Mayer JE Jr. Functional living trileaflet heart valves grown in vitro. Circulation. 2000;102(19 Suppl 3):III44-9.

2. Schmidt CE, Baier JM. Acellular vascular tissues: natural biomaterials for tissue repair and tissue engineering. Biomaterials. 2000;21(22):2215-31.

3. Schmidt D, Hoerstrup SP. Tissue engineered heart valves based on human cells. Swiss Med Wkly. 2006;136(39-40):618-23.

4. Schmidt D, Stock UA, Hoerstrup SP. Tissue engineering of heart valves using decellularized xenogeneic or polymeric starter matri ces. Philos Trans R Soc Lond B Biol Sci. 2007;362(1484): 1505-12.
5. Kasimir MT, Rieder E, Seebacher G, Nigisch A, Dekan B, Wolner $E$, Weigel $G$, Simon P. Decellularization does not eliminate thrombogenicity and inflammatory stimulation in tissue-engineered porcine heart valves. J Heart Valve Dis. 2006;15(2):278-86

6. Klopsch $C$, Steinhoff $G$. Tissue-engineered devices in cardiovascular surgery. Eur Surg Res. 2012;49(1):44-52.

7. Steinhoff G, Stock U, Karim N, Mertsching H, Timke A, Meliss RR, Pethig K, Haverich A, Bader A. Tissue engineering of pulmonary heart valves on allogenic acellular matrix conduits: in vivo restoration of valve tissue. Circulation. 2000;102(19 Suppl 3):III50-5.

8. Badylak SF, Weiss DJ, Caplan A, Macchiarini P. Engineered whole organs and complex tissues. Lancet. 2012;379(9819): 943-52.

9. Lopes SA, Costa FD, Paula JB, Dhomen P, Phol F, Vilani R, Roderjan $J G$, Vieira ED. Decellularized heterografts versus cryopreserved homografts: experimental study in sheep model. Rev Bras Cir Cardiovasc. 2009;24(1):15-22.

10. Van Nooten $G$, Somers P, Cornelissen M, Bouchez S, Gasthuys $F$, Cox E, Sparks L, Narine K. Acellular porcine and kangaroo aortic valve scaffolds show more intense immune-mediated calcification than cross-linked Toronto SPV valves in the sheep model. Interact Cardiovasc Thorac Surg. 2006;5(5):544-9.

11. Popandopulo AG, Petrova $M V$. Acellular matrix as a substrate for tissue-engineered graft of heart valve. Cell and Organ Transplantology. 2013; 1(1):52-55.

12. Grauss $R W$, Hazekamp $M G$, van Vliet $S$, Gittenberger-de Groot $A C$, DeRuiter $M C$. Decellularization of rat aortic valve allografts reduces leaflet destruction and extracellular matrix remodeling. J Thorac Cardiovasc Surg. 2003;126(6):2003-10.

13. Rieder E, Seebacher G, Kasimir MT, Eichmair E, Winter B, Dekan B, Wolner E, Simon P, Weigel G. Tissue engineering of heart valves: decellularized porcine and human valve scaffolds differ importantly in residual potential to attract monocytic cells. Circulation. 2005;111(21):2792-7.

14. Tomazic BB, Edwards WD, Schoen FJ. Physicochemical characterization of natural and bioprosthetic heart valve calcific deposits: implications for prevention. Ann Thorac Surg. 1995;60(2 Suppl):S322-7.

15. Rosanova IB, Mischenko BP, Zaitsev VV, Vasin SL, Sevastianov $V I$. The effect of cells on biomaterial calcification: experiments with in vivo diffusion chambers. J Biomed Mater Res. 1991; 25(2):277-80.

16. Akatov BC, Fesenko NI, Solov"ev VV, Fadeeva IE, Chekanov AV, Muratov RM, Britikov DV, Sachkov AS. Inhibition of calcification of heart valves' transplants by their devitalization. Kletochnaja transplantalogija i tkanevaja inzhenerija. 2010; 5(1):41-46.

17. Korzhevskij D, Giljarov A. Fundamentals of histological techniques. St. Petersburg, SpecLit, 2010; 95 p.

18. Education Guide: Immunohistochemical Staining Methods: Pathology. Eds GL Kumar, L Rudbeck. Carpinteria, 2009;162 p.

19. Popandopulo AG, Ignatov DJu, Slipchenko IO, Vasil'ev RG, Merkulova $E V$, Gerasimov IG. Effect of culturing factors on viability of fetal human fibroblasts. Vestnyk Neotlozhnoy i Vosstanovitelnoy Meditsyny. 2003; 4(2): 323-325.

20. Eghbali $M$. Cardiac fibroblasts: function, regulation of gene expression, and phenotypic modulation. Basic Res Cardiol. 1992; 87 Suppl 2:183-9.

21. Hannun YA, Obeid LM. Ceramide and the eukaryotic stress response. Biochem Soc Trans. 1997;25(4):1171-5.

22. Weedon D, Searle J, Kerr JF. Apoptosis. Its nature and implications for dermatopathology. Am J Dermatopathol. 1979;1(2): 133-44.

23. Robinson KA, Li J, Mathison M, Redkar A, Cui J, Chronos NA, Matheny $R G$, Badylak $S F$. Extracellular matrix scaffold for cardiac repair. Circulation. 2005;112(9 Suppl):I135-43.

24. Ross M, Wojciech P. Histology: A Text and Atlas. Lippincott, Williams \& Wilkins, 2010; 235-241.

Received 07.05.14 